\title{
Validasi Struktur Internal Alat Ukur Refleksi Diri Adaptif melalui CFA
}

\author{
Siti Bahiyah $^{1} \mathcal{E}$ Setiawati Intan Savitri ${ }^{2}$ \\ 1,2Fakultas Psikologi Universitas Mercu Buana Jakarta
}

\begin{abstract}
Adaptive self reflection could be done if people could react positively when analyze negative experienced by reflecting emotions, allowing theself to reconstruct the feelings and meaning of the experience rather than recounting what has happened and what is perceived or avoiding it (self-distancing). The purpose of this study is to developed adaptive self reflection questionnaire by validating internal structure some of scales that have the same relation with adaptive self reflection construct. This study used a quantitative approach with Confirmatory Factor Analysis (CFA) method involving 100 respondents in the trial and 306 respondents in the next test. The Adaptive self reflection questionnaire that produced in this study consisted of 15 items that measure three dimensions, namely theemotional reactivity, thought content, and avoidance. The Adaptive self reflection questionnaire proved to be valid and reliable $(C R=0.80)$. The test results proved that the measuring adaptive self reflection questionnaire meet the unidimensionality assumption.
\end{abstract}

Keywords: adaptive self-reflection; avoidance; emotional reactivity; thought content; selfdistancing

Abstrak. Seseorang mencapai refleksi diri adaptif apabila dapat bereaksi secara positif ketika mengingat peristiwa negatif yang pernah dialaminya dengan melakukan refleksi diri, membiarkan diri merekonstruksi perasaan dan makna dari pengalaman daripada mengulang apa yang telah terjadi dan apa yang dirasakan secara nyata atau melakukan penghindaran (self-distancing). Tujuan penelitian ini merancang alat ukur refleksi diri adaptif dengan cara memvalidasi struktur internal beberapa alat ukur sejenis yang berkaitan dengan refleksi diri dengan menggunakan metode Confirmatory Faktor Analysis (CFA) yang melibatkan 100 responden pada tahap uji coba dan 306 responden pada pengujian berikutnya. Alat ukur refleksi diri adaptif yang dihasilkan dari penelitian ini terdiri dari 15 aitem yang mengukur tiga dimensi yaitu reaksi emosi, konten pikiran dan penghindaran. Alat ukur refleksi diri adaptif terbukti valid dan reliable $(C R=0.80)$. Hasil pengujian membuktikan bahwa alat ukur refleksi diri adaptif ini memenuhi asumsi unidimensionalitas.

Kata kunci: konten pikiran; penghindaran; self-distancing; reaksi emosi; refleksi diri adaptif

Hampir semua orang mengetahui keputusasaan, merenungkan perasaan bagaimana rasanya berpikir dalam yang tersakiti, mengulang-ulang suatu

${ }^{1}$ Korespondensi mengenai artikel ini dapat melalui: siti.bahiyah06@gmail.com;

2intan.savitri@mercubuana.ac.id 
penghinaan yang nyata maupun yang merupakan imajinasi dan terus menenggelamkan diri dalam kecemasan. Saat seseorang berpikir seperti itu, dapat dipahami mengapa merenung menyebabkan seseorang bertahan dalam kecemasan, kemarahan, atau pola pikir yang suram (Wade \& Tavris, 2007). Asumsi yang berlaku pada masyarakat umum menyatakan bahwa seseorang seringkali perlu berkonfrontasi dengan kemarahan, kecemasan, dan depresi untuk mempelajari bagaimana mengendalikan dan mengatur hal-hal tersebut (Kross, Duckworth, Ayduk, Tsukayama, \& Mischel, 2011). Ketika seseorang mencoba menganalisis perasaan, pikiran negatif menjadi mudah diakses. Hal ini membuat seseorang terlibat dalam lingkaran setan "ruminasi" yang dalam jangka pendek menyebabkan seseorang mempertahankan dan memperburuk tekanan, merongrong kesehatan dan kesejahteraan dari waktu ke waktu (Kross \& Ayduk, 2008). Namun, melakukan analisis perasaan dengan perspektif self distancing mampu memfasilitasi refleksi diri adaptif (Ayduk \& Kross, 2010). Sehingga pada dasarnya bukan perenungan yang menyebabkan lamanya seseorang merasakan depresi dan emosi negatif, melainkan jenis perenungan yang dilakukan (Wade \& Tavris, 2007).

Dari perspektif sosio-budaya, gagasan memberi jarak (distancing), baik dari diri sendiri maupun situasi langsung, terjadi melalui penggunaan mediator semiotik untuk memilih pengalaman afektif atau situasi tersebut, selanjutnya jarak seperti itu memungkinkan diri untuk bertindak atas diri sendiri dan situasi (Gillespie, 2007). Seseorang dapat mengkonseptualisasikan refleksi diri sebagaimana timbul melalui internalisasi perspektif yang dimiliki orang lain terhadap diri sendiri, diikuti dengan mengambil perspektif orang lain terhadap diri sendiri. Atau lebih umum lagi, orang bisa memikirkan refleksi diri yang timbul melalui dialog internal antara perspektif yang diinternalisasi (Gillespie, 2007).

Penelitian Trapnell dan Campbell (1999), menunjukkan bahwa perhatian yang berfokus pada diri sendiri atau pemikiran berulang tentang diri memiliki fungsi adaptif dan maladaptif. Treynor, Gonxalez, dan Nolen-Hoeksema (2003) juga menunjukkan bahwa perhatian terfokus pada diri sendiri dapat dibagi menjadi faktor perenungan reflektif adaptif dan maladaptif. Perenungan reflektif adaptif ditandai sebagai upaya untuk memahami alasan depresi suasana hati, dan perenungan reflektif maladaptif ditandai sebagai pengharapan akan konsekuensi negatif dari gejala depresi. Untuk mengetahui apakah seseorang melakukan perenungan secara adaptif atau maladaptif terhadap peristiwa negatif yang dialaminya perlu dilakukan melalui suatu pengukuran. Perspektif seseorang dalam melakukan refleksi terhadap pengalaman negatifnya akan memengaruhi reaksi emosi secara psikologis, perilaku penghindaran dan konten pemikirannya yang mengarahkan seseorang kepada kecenderungan reflektif atau ruminasi.

Sebagaimana umumnya variabel psikologis, refleksi diri adaptif bersifat laten dan hanya dapat diamati melalui sampel perilaku. Merancang aitem-aitem yang mampu menggali refleksi diri adaptif merupakan hal yang menarik dalam perancangan alat ukur refleksi diri adaptif. Penelitian ini bertujuan untuk memvalidasi struktur internal aitem-aitem yang terdapat dalam alat ukur yang memiliki konstruk yang berkaitan dengan refleksi diri dengan menggunakan metode Confirmatory Factor Analysis. Diharapkan alat ukur ini dapat digunakan di Indonesia dalam konteks 
remaja madya yang dapat membantu untuk memperoleh gambaran tentang refleksi diri sebagai pendukung perkembangan emosi secara positif, penyelesaian masalah serta pengambilan keputusan.

\section{Kesadaran (consciousness)}

Feldman dalam Sobur (2003) menjelaskan kesadaran (consciousness) merupakan dasar bagi seseorang untuk memahami lingkungan sekitar dan dunia pribadi yang tidak dapat diamati oleh orang lain. Kesadaran adalah sebuah sensasi, pemikiran, dan perasaan terhadap pengalaman yang sudah dilalui. Palmer dalam Sobur (2003) menyebutnya sebagai proses mengidentifikasi dan memiliki pikiran, perasaan, dan sensasi serta aksi ragawi atau kandungan mental yang dikenal dan bisa dipanggil. Fenigstein, Scheier, dan Buss (1975) menemukan ada dua aspek terpisah dari kesadaran diri (selfconsciousness). Pertama, berkaitan dengan kognitif, merenungkan diri pribadi, dan penekanan lain pada kesadaran dan perhatian sebagai stimulus sosial. Dimensi kesadaran diri pribadi (private of selfconsciousness) serupa dengan konsep introvert Jung yang pada umumnya berorientasi pada dunia internal, sedangkan dorongan kesadaran diri pribadi lebih spesifik, fokusnya adalah pada pemikiran dan refleksi yang berhubungan dengan diri. Kedua, kesadaran diri publik (public self-consciousness) terkait dengan konsepsi Mead (1934) yang berpendapat bahwa kesadaran diri itu muncul ketika orang tersebut sadar akan perspektif orang lain, kemudian dia bisa memandang dirinya sebagai objek sosial. Penekanannya disini jelas pada reaksi orang lain terhadap diri sendiri. Inti dari kesadaran diri publik adalah diri sebagai objek sosial (Fenigstein, Scheier dan Buss, 1975).

\section{Refleksi diri}

Refleksi diri dapat didefinisikan sebagai pengalaman fenomenologis sementara dimana diri menjadi objek bagi diri sendiri. Refleksi diri berdasarkan perspektif sosial budaya adalah gagasan memberi jarak, baik dari diri sendiri maupun situasi langsung, terjadi melalui mediator semiotik (analisis teks/simbol), atau melalui proses penamaan terhadap pengalaman afektif atau memberi jarak dari situasi yang menjauhkan individu dari pengalaman atas situasi tersebut. Penamaan pengalaman afektif atau situasi akan menjauhkan individu dari pengalaman atau situasi tersebut, selanjutnya jarak seperti itu memungkinkan diri untuk bertindak atas diri sendiri dan situasi (Gillespie, 2007). Menurut teori kesadaran diri (self awareness) yang dikenal sebagai teori kesadaran diri obyektif, terdiri dari perhatian pada suatu waktu tertentu baik yang diarahkan sendiri atau berorientasi eksternal. Kesadaran diri yang diarahkan pada diri sendiri atau obyektif adalah keadaan di mana kesadaran difokuskan secara eksklusif pada diri sendiri dan akibatnya individu menghadiri keadaan sadar akan sejarah pribadinya, tubuhnya, atau aspek pribadi lainnya dari dirinya sendiri. Sebaliknya, kesadaran diri yang berorientasi pada eksternal atau subyektif, disarankan untuk menjadi standar perhatian individu, melibatkan perhatian yang terfokus pada lingkungan eksternal. Berbeda dengan keadaan kesadaran diri subyektif, yang ditandai oleh arahan dan kontrol perasaan (karena individu adalah 'subjek' dan lingkungannya adalah 'objek') (Gerace, Day, Casey, \& Mohr, 2017). 
Perspektif self-distancing dan self-immersed

Self-distancing berfokus pada penjelasan mekanisme psikologis yang memungkinkan seseorang merenungkan pengalaman negatif secara adaptif, dengan cara yang memungkinkan seseorang membuat makna dari pengalamannya agar tidak menjadi sumber kesusahan yang berkelanjutan. Cara seseorang ketika memikirkan masa lalu dan alasannya dengan mengambil langkah mundur sebagai pengamat jarak jauh disebut self-distancing, sedangkan selfimmersed memotivasi seseorang untuk memahami pengalamannya dengan cara mengulang kejadian melalui matanya sendiri (Kross et al., 2011). Kross berhipotesis bahwa seseorang yang melakukan refleksi secara adaptif terhadap perasaan negatifnya seringkali gagal karena berfokus pada pengalaman mereka dari perspektif immersed (tenggelam) secara psikologis yang membuat seseorang sulit untuk beralasan secara objektif tanpa terjebak dengan detail yang membangkitkan emosi terhadap apa yang terjadi padanya. Diperlukan mekanisme yang memungkinkan seseorang "mundur selangkah" dari pengalaman mereka sehingga bisa melaluinya secara lebih efektif. Proses ini disebut Self-distancing. Jarak psikologis adalah proses dimana pengalaman egosentris seseorang terhadap stimulus di sini dan sekarang berkurang. Penelitian di berbagai bidang menunjukkan pentingnya konstruksi ini untuk pengendalian diri dan penanganan adaptif (Ayduk \& Kross, 2010). Konstruksi jarak psikologis juga muncul dalam penelitian klinis, teori dan praktik. Alford dan Beck menulis "menjauh" mengacu pada kemampuan untuk melihat pemikiran (atau keyakinan) seseorang sebagai kontruksi realitas dan bukan sebagai kenyataan itu sendiri. Proses ini diidentifikasi sebagai prasyarat penting untuk terapi kognitif yang efektif (Ayduk, Kross, 2010; Kross, Ayduk, 2017).

Self-distancing memfasilitasi refleksi diri adaptif

Menganalisis emosi seputar pengalaman negatif masa lalu akan menyebabkan ruminasi maladaptif ketika jarak psikologis rendah yang disebut sebagai self-immersion (peredaman diri), sementara refleksi diri adaptif adalah saat jarak psikologis dari diri sendiri tinggi disebut sebagai selfdistancing. Salah satu cara untuk mengarahkan orang menjauh dari diri adalah dengan memanipulasi jenis perspektif diri yang diadopsi ketika seseorang berfokus untuk memahami perasaannya. Secara khusus, penelitian sebelumnya menunjukkan bahwa seseorang dapat mengingat pengalaman otobiografi dari perspektif self-immersed dengan memvisualisasikan peristiwa yang terjadi melalui mata sendiri atau perspektif self-distanced dimana seseorang melihat dirinya dalam pengalamannya dari perspektif seorang pengamat. Dari kedua perspektif yang berbeda ini hipotesis penelitian yang dihasilkan adalah mengadopsi dan mempertahankan perspektif self-distanced ketika seseorang merefleksikan emosinya harus membiarkan diri merekonstruksi perasaan dan makna dari pengalaman daripada mengulang apa yang telah terjadi dan apa yang dirasakan secara nyata (Ayduk \& Kross, 2010).

Pergeseran isi pikiran seseorang terhadap pengalaman masa lalu dengan menarasikan peristiwa (recounting) menjadi menafsirkan peristiwa (reconstruing) pada gilirannya mengarahkan tingkat emosional yang lebih rendah dalam jangka waktu pendek. Selanjutnya self-distancing dimanipulasi secara ekperimental terhadap reaksi negatif dari waktu ke waktu 
termasuk reaktivitas fisiologis, ruminasi dan pemeliharaan reaktivitas emosional dalam jangka waktu panjang (Kross, Ayduk, 2008).

Terkait dengan hal tersebut Kross dan Ayduk meneliti tentang hubungan antara self-distancing, reaktivitas emosional, konten pemikiran, dan penghindaran. Penemuan penelitian menunjukkan bahwa self-distancing spontan berkaitan dengan profil respon yang sama terhadap reaktivitas emosional dan konten pikiran karena self-distancing dimanipulasi secara eksperimen. Secara khusus, semakin seseorang menjauhkan diri secara spontan selama merenungkan pengalaman masa lalu, semakin sedikit menceritakan kejadian tersebut dan semakin merekonstruksinya (recounting menuju reconstruing). Pergeseran dalam isi pikiran ini pada akhirnya menjelaskan hubungan antara self-distancing dengan reaktivitas emosional. Self-distancing tidak berhubungan dengan avoidance (penghindaran) secara signifikan. Oleh karenanya fungsi adaptif self-distancing dari waktu ke waktu tidak dapat dijelaskan dengan penghindaran. Self-distancing secara positif berhubungan dengan persepsi seseorang tentang bagaimana menyelesaikan pengalaman yang diingatnya. Hal ini memberi bukti bahwa Self-distancing spontan memfasilitasi refleksi diri adaptif dari waktu ke waktu dan melakukannya dengan memengaruhi cara seseorang dalam menafsirkan pengalaman masa lalunya (Ayduk \& Kross, 2010).

Kross dan Ayduk menggarisbawahi bahwa seseorang memungkinkan untuk merenungkan pengalaman negatifnya tanpa ruminasi. Sebuah strategi dibutuhkan untuk menjauhkan seseorang dari perasaan sehingga bisa merekonstruksi perasaan secara adaptif. Suatu cara untuk mengarahkan orang ke jarak jauh adalah dengan memanipulasi jenis perspektif diri yang diadopsi ketika seseorang berfokus untuk memahami perasaan mereka sehingga dapat mengaktifkan dan menganalisis perasaan yang memungkinkan untuk terlibat dalam rekonstrual yang memfasilitasi refleksi diri adaptif. Sebaliknya ketika orang menganalisis pengalaman dari perspektif self immersed (diredam sendiri) cenderung berfokus pada pengulangan secara nyata yang membangkitkan detail pengalaman dan memperkecil kemungkinan seseorang dapat merekonstruksi perasaannya (Ayduk \& Kross, 2010).

\section{Refleksi diri maladaptif: Berfokus pada} pengalaman negatif

Usaha seseorang untuk memahami emosi mereka sering menjadi bumerang. Ruminasi mengacu pada proses dimana seseorang memusatkan perhatian berulang kali dan pasif pada apa yang mereka rasakan dan merasakannya dengan suatu cara tertentu (Nolen-Hoeksema, Wisco, \& Lyubomirsky, 2008). Orang melakukan ini karena percaya bahwa memahami perasaan dapat memperbaiki mood (suasana hati). Namun memusatkan perhatian diri pada konten negatif meningkatkan aksesibilitas pikiran dan emosi negatif lainnya, mengorbankan kemampuan pemecahan masalah dan akhirnya berfungsi untuk melanggengkan daripada mengurangi suasana hati negatif (Nolen-Hoeksema et al, 2008). Pemusatan perhatian pada konten negatif akan menimbulkan ruminasi. Ruminasi merupakan strategi konfrontasi maladaptif yang melanggengkan kesusahan dengan meningkatkan kognisi negatif, mengganggu pemecahan masalah dan perilaku instrumental serta mengurangi dukungan sosial. Ruminasi dengan penghindaran menyebabkan seseorang terhindar dari aspek kerugian yang menyakitkan sehingga menghambat 
penyesuaian terhadap kesusahan (Eisma \& Stroebe, 2017).

\section{Metode}

\section{Responden}

Responden penelitian adalah 100 siswa SMA pada tahap uji coba dan 306 siswa pada tahap pelaksanaan yang diambil dengan teknik simple random sampling (sampling acak sederhana). Mereka adalah siswa kelas X, XI, dan XII yang yang usianya berkisar antara 15-18 tahun atau termasuk dalam kategori remaja madya. Responden pada tahap uji coba tidak diikutsertakan lagi pada tahap pelaksanaan. Berdasarkan perspektif psikologis, karakteristik remaja sesuai dengan tema yang diteliti yaitu refleksi diri adaptif. Teori-teori psikologis dan psikososial mengkaji hubungan antara mekanisme penyesuaian psikologis dengan kondisikondisi sosial yang memfasilitasinya (memengaruhinya).

\section{Prosedur}

Tahap persiapan, peneliti melakukan kajian literatur refleksi diri adaptif untuk merancang alat ukur yang akan digunakan dalam penelitian. Kemudian alat ukur refleksi diri adaptif yang dirancang didiskusikan dengan lima pakar yang memahami konstruk refleksi diri adaptif untuk mendapatkan expert judgement. Lima pakar yang memberikan reviu terhadap rancangan alat ukur refleksi diri adaptif memiliki spesifikasi keahlian di bidang psikologi klinis anak, psikologi klinis dewasa, psikologi sosial dan narrative therapy. Kelima pakar memberikan saran terhadap rancangan alat ukur refleksi adaptif pada segi penerjemahan lima skala yang menjadi acuan, penggunaan bahasa pada pernyataan dan ketepatan aspek yang diukur dengan aitem-aitemnya untuk tiap dimensi. Beberapa contoh saran perubahan pada penerjemahan antara lain terjemah untuk pernyataan "Think about how alone you feel" pada skala Ruminative responses Scale (RRS) diberikan saran terjemah menjadi "Pikirkan bagaimana anda merasa kesepian", pernyataan "After an argument is over, $i$ keep fighting with this person in my imagination" pada Anger Rumination Scale (ARS) saran terjemah adalah "setelah sebuah argumen selesai, saya terus bertarung dengan orang ini dalam imajinasi saya" dan pernyataan "My behaviour often puzzles me" pada The Self Reflection and Insight Sclae (SRIS) diberikan saran terjemah "Perilaku saya sering membingungkan diri saya sendiri". Pernyataan pada aitem-aitem alat ukur refleksi diri adaptif dengan dimensidimensinya dinilai oleh kelima ahli telah sesuai dan dapat digunakan untuk rancangan alat ukur refleksi diri adaptif. Setelah aitem-aitem direvisi, alat ukur diuji coba untuk menguji validitas dan reliabilitasnya dengan melakukan analisis aitem secara kuantitatif.

Tahap uji coba, pada tahap ini dilakukan pengujian validitas, analisis aitem dan uji asumsi unidimensionalitas menggunakan CFA. Apabila hasil CFA menunjukkan bahwa alat ukur memenuhi asumsi unidimensionalitas, maka dapat dilakukan pengujian validitas dan reliabilitas model pengukuran refleksi diri adaptif dengan menggunakan CFA kembali untuk menentukan apakah model alat ukur refleksi diri adaptif sudah fit dan terdiri dari aitem-aitem yang valid dan reliabel. Model pengukuran dikatakan fit apabila $p$ value lebih dari 0.05 dan RMSEA mendekati 0 serta semua variabel observable memberikan sumbangan yang signifikan terhadap variabel laten, hal ini dapat ditunjukkan berdasarkan T-value. Apabila 
T-value tiap-tiap aitem tidak kurang dari 1,96 untuk taraf signifikansi 0.05 (tidak berwarna merah pada program Lisrel) maka aitem dikatakan valid artinya dapat mengukur apa yang hendak diukur (Retnawati, 2016).

Tahap pelaksanaan, alat ukur yang lolos proses pada tahap uji coba diujikan pada 306 responden, kemudian hasilnya dianalisis dengan menggunakan CFA. Peneliti melakukan pengujian First Order CFA terhadap dimensi reaksi emosi, dimensi konten pikiran dan dimensi penghindaran. Setelah tercapai model pengukuran refleksi diri adaptif dengan item yang valid dan reliabel, peneliti melakukan pengujian second order Confirmatory Factor Analysis (CFA) sehingga dihasilkan model pengukuran refleksi diri adaptif yang fit dan dapat diterima dengan seluruh aitem valid dan reliabel.

\section{Spesifikasi alat ukur}

Alat ukur yang akan dikonstruksi dalam penelitian ini adalah alat ukur refleksi diri adaptif, tergolong typical performance test yang tidak mengandung jawaban benar dan salah. Responden menentukan pilihan jawaban dengan menyesuaikan karakteristik yang ada pada dirinya. Teknik penskalaan yang digunakan pada penyusunan alat ukur ini adalah Skala Likert dengan mengkategorikan aitem menjadi favorable (mendukung konstruk yang akan diungkap) dan unfavorable (negasi dari konstruk yang akan diungkap). Tiap aitem menyediakan 5 pilihan respon mulai dari "sangat sesuai" sampai "sangat tidak sesuai". Skala tersebut dipilih agar responden memberikan respon yang lebih bervariasi dalam rentang tertentu dan dapat mengevaluasi pernyataan yang ada sesuai dengan kondisi dirinya. Penetapan dimensi alat ukur refleksi diri adaptif berdasarkan review beberapa jurnal penelitian tentang refleksi diri serta alat ukur yang telah terstandarisasi. Kross dan Ayduk meneliti tentang hubungan antara self-distancing, reaktivitas emosional, konten pikiran, dan penghindaran (avoidance). Berdasarkan penelitian Ayduk dan Kross tersebut, peneliti menetapkan reaktivitas emosional, konten pikiran dan penghindaran sebagai dimensi dalam alat ukur refleksi diri adaptif. Kemudian dari ketiga dimensi tersebut ditetapkan aspekaspek yang akan dijadikan dasar untuk membuat indikator serta aitem-aitemnya. Gambaran mengenai aspek pada alat ukuralat ukur yang digunakan sebagai acuan dijelaskan dalam tabel 1.

Berdasarkan alat ukur yang dijelaskan pada tabel 1, peneliti merancang alat ukur awal terdiri dari 99 aitem yang ditetapkan berdasarkan hasil pemeriksaan oleh beberapa expert. Tabel 2 menjelaskan aspek dari dimensi alat ukur refleksi diri adaptif yaitu reaksi emosi, konten pikiran dan penghindaran. 
Tabel 1

Skala acuan alat ukur refleksi diri adaptif

\begin{tabular}{|c|c|c|}
\hline Skala & Jurnal Sumber & Aspek \\
\hline $\begin{array}{l}\text { Ruminative Responses } \\
\text { Scale } \\
\text { (RRS) }\end{array}$ & $\begin{array}{l}\text { Rumination } \\
\text { Reconsidered: } \\
\text { A Psychometric Analysis } \\
\text { (Treynor, Gonzalez, } \\
\text { Hoeksema, 2003) }\end{array}$ & $\begin{array}{l}\text { Refleksi } \\
\text { Menyarankan adanya perubahan tujuan agar } \\
\text { terlibat dalam pemecahan masalah kognitif } \\
\text { untuk meringankan gejala depresi seseorang. } \\
\text { Merenun (brooding) Didefinisikan oleh Webster } \\
\text { sebagai suasana hati murung } \\
\text { Ruminasi } \\
\text { Bisa menjadi maladaptif ketika seorang indi- } \\
\text { vidu tidak dapat menyelesaikan perbedaan } \\
\text { antara kekuatan saat ini dan tidak tercapainya } \\
\text { tujuan yang diinginkan. }\end{array}$ \\
\hline $\begin{array}{l}\text { The Rumination- } \\
\text { Reflection } \\
\text { Questionnaire } \\
\text { (RRQ) }\end{array}$ & $\begin{array}{l}\text { Private self- } \\
\text { consciousness and the- } \\
\text { five factor model of } \\
\text { personality: } \\
\text { Distuingshing } \\
\text { rumintaion from } \\
\text { reflection. } \\
\text { ( Trapnell, Campbell, } \\
\text { 1999) }\end{array}$ & $\begin{array}{l}\text { Ruminasi } \\
\text { Ruminasi memberikan konsepsi ringkas } \\
\text { tentang rasa percaya diri dimotivasi oleh } \\
\text { persepsi ancaman, kerugian, atau ketidak- } \\
\text { adilan untuk diri sendiri. } \\
\text { Refleksi } \\
\text { Refleksi memberikan konsep ringkas tentang } \\
\text { rasa percaya diri dimotivasi oleh keinginta- } \\
\text { huan atau kepentingan epistemis dalam diri. }\end{array}$ \\
\hline $\begin{array}{l}\text { Anger rumination in } \\
\text { Australia and Spain } \\
\text { (ARS) }\end{array}$ & $\begin{array}{l}\text { Anger rumination in } \\
\text { Australia and Spain: } \\
\text { Validation of the Anger } \\
\text { Rumination Scale. } \\
\text { (Cejudo, Salguero, } \\
\text { Dymand, Sancho, } \\
\text { Love, 2017) }\end{array}$ & $\begin{array}{l}\text { Ruminasi } \\
\text { Bentuk gaya berpikir yang berkaitan dengan } \\
\text { menanggapi tekanan dengan berfokus kembali } \\
\text { pada penyebab tekanan, bagaimana hal itu } \\
\text { menjadi penyebab, dan konsekuensi apa yang } \\
\text { mungkin ditimbulkan }\end{array}$ \\
\hline $\begin{array}{l}\text { Self-Critical Rumination } \\
\text { Questionnaire (SCRQ) }\end{array}$ & $\begin{array}{l}\text { The Metacognitions } \\
\text { about Self-Critical } \\
\text { Rumination } \\
\text { Questionnaire. } \\
\text { (Kolubinski, Lawrence, } \\
\text { Spada, 2017) }\end{array}$ & $\begin{array}{l}\text { Self-Critical (kritik diri) } \\
\text { Mengacu pada serangkaian penilaian diri yang } \\
\text { terus-menerus dan negatif, yang seringkali } \\
\text { tidak disengaja, yang dibuat seseorang tentang } \\
\text { diri mereka sendiri. }\end{array}$ \\
\hline $\begin{array}{l}\text { Self-Reflection and } \\
\text { Insight Scale (SRIS) }\end{array}$ & $\begin{array}{l}\text { The Self-Reflection and } \\
\text { Insight Scale: } \\
\text { A New Measure Of } \\
\text { Privat Self- } \\
\text { Consciousness. } \\
\text { (Grant, Franklin, } \\
\text { Langford, 2002) }\end{array}$ & $\begin{array}{l}\text { Insight } \\
\text { Terkait dengan kesadaran keadaan internal. } \\
\text { Kesadaran akan keadaan internal dan konstruk } \\
\text { pemahaman terkait dikaitkan dengan } \\
\text { kemampuan untuk mengidentifikasi dan } \\
\text { mengekspresikan perasaan. } \\
\text { Refleksi dan insight sangat penting bagi proses } \\
\text { pengaturan diri. }\end{array}$ \\
\hline
\end{tabular}


Tabel 2

Dimensi dan aspek alat ukur refleksi diri adaptif

\begin{tabular}{|c|c|}
\hline Dimensi & Aspek \\
\hline \multirow{9}{*}{$\begin{array}{l}\text { Reaksi Emosi } \\
\text { Reaksi yang timbul saat subjek } \\
\text { mengingat peristiwa negatif di } \\
\text { masa lalu berupa perasaan kecewa, } \\
\text { marah, sakit dan reaksi fisik. } \\
\text { Individu menilai emosinya saat ini }\end{array}$} & Refleksi (RRS) \\
\hline & $\begin{array}{l}\text { Adanya perubahan tujuan agar terlibat dalam pemecahan } \\
\text { masalah kognitif untuk meringankan gejala depresi }\end{array}$ \\
\hline & Refleksi (RRQ) \\
\hline & Memberikan konsep ringas tentang rasa percaya diri yang \\
\hline & $\begin{array}{l}\text { dimotivasi oleh keingintahuan atau kepentingan epistemis } \\
\text { dalam diri }\end{array}$ \\
\hline & Ruminasi (Brooding) (RRS) \\
\hline & $\begin{array}{l}\text { Perbandingan situasi pasif saat ini dengan beberapa orang } \\
\text { yang tidak mencapai standar }\end{array}$ \\
\hline & Ruminasi (RRQ) \\
\hline & $\begin{array}{l}\text { Konsepsi ringkas tentang rasa percaya diri dimotivasi oleh } \\
\text { persepsi ancaman, kerugian dan ketidak adilan }\end{array}$ \\
\hline \multirow{6}{*}{$\begin{array}{l}\text { Konten pikiran } \\
\text { Hal yang muncul dalam pemikiran } \\
\text { subjek ketika memikirkan } \\
\text { pengalaman marah. }\end{array}$} & Recounting \\
\hline & Menarasikan peristiwa. \\
\hline & $\begin{array}{l}\text { Memusatkan perhatian pada rantai peristiwa spesifik yang } \\
\text { terjadi di suatu tempat. }\end{array}$ \\
\hline & Reconstruing \\
\hline & Menafsirkan atau memahami sebab depresi. \\
\hline & $\begin{array}{l}\text { Mengekspresikan persepsi subjektif wawasan dan penyele- } \\
\text { saian, realisasi yang membuat individu berpikir dan merasa } \\
\text { berbeda tentang pengalamannya }\end{array}$ \\
\hline Penghindaran (Avoidance). & Mencoba untuk tidak memikirkan peristiwa itu. \\
\hline $\begin{array}{l}\text { Subjek berusaha menghindar untuk } \\
\text { memikirkan kejadian yang } \\
\text { membuatnya marah ketika diminta } \\
\text { untuk mengingat. }\end{array}$ & Mencoba menekan perasaan tentang peristiwa itu. \\
\hline
\end{tabular}

\section{Teknik analisis data}

Untuk menguji validitas konstruk alat ukur refleksi diri adaptif ini menggunakan pendekatan analisis faktor berupa Confirmatory Factor Analysis (CFA). Adapun logikanya adalah dengan cara membandingkan sejauh mana matriks korelasi hasil estimasi menggunakan teori dengan matriks korelasi yang diperoleh dari data. Dalam hal ini, yang dimaksud adalah bahwa seluruh aitem mengukur satu hal yang sama (unidimensional) yaitu konstruk yang hendak diukur. Jika tidak ada perbedaan yang signifikan antara teori dengan data, maka berarti bahwa seluruh aitem itu mengukur hal yang sama (unidimensional). Pengujian analisis CFA dilakukan dengan bantuan software LISREL 8.80. Setelah diukur validitasnya, kemudian diuji reliabilitas dari aitemaitem.

\section{Penilaian model fit}

Peneliti menggunakan indikator-indikator goodness of fit dalam menilai fit suatu model. Goodness of fit suatu model dapat dinilai 
berdasarkan kriteria fit seperti disajikan dalam tabel 3.

Tabel 3

Goodness of fit model pengukuran

\begin{tabular}{lc}
\hline Goodness of fit Index & Kriteria 'fit' \\
\hline$X^{2}$-Chi square & Diharapkan kecil \\
Probability & $>0.05$ \\
RMSEA & $<0.08$ \\
GFI & $>0.90$ \\
AGFI & $>0.90$ \\
CFI & $>0.90$ \\
IFI & $>0.90$ \\
\hline
\end{tabular}

Sumber: Ghozali, I., \& Fuad. (2012). Structural Equation Modeling: Teori, Konsep, dan Aplikasi dengan Program LISREL 8.80 Edisi III. Semarang: Universitas Diponegoro

Evaluasi model pengukuran

Dalam mengevaluasi model pengukuran peneliti berfokus pada hubungan-hubungan antara variabel laten dan indikatornya. Tujuan evaluasi model pengukuran ini adalah untuk menentukan validitas dan reliabilitas indikator-indikator dari suatu konstruk. Uji validitas bertujuan untuk menentukan kemampuan suatu indikator dalam mengukur variabel laten. Sedangkan uji reliabilitas adalah suatu pengujian untuk menentukan konsistensi pengukuran indikator-indikator dari variabel laten. Cut-offs untuk kriteria model yang dapat diterima dijelaskan pada tabel 4 .

Composite Reliability (CR) sering disebut juga Construct Reliability dapat digunakan informasi pada loading factor indikator dan error variance pada bagian standardized solution dengan menggunakan rumus :

$$
\mathrm{CR}=\frac{\left(\sum_{i=1}^{n} \lambda_{i}\right)^{2}}{\left(\sum_{i=1}^{n} \lambda_{i}\right)^{2}+\left(\sum_{i=1}^{n} \delta_{i}\right)}
$$

Keterangan:

$$
\begin{aligned}
\mathrm{CR}= & \text { Construct Reliability } \\
\lambda \mathrm{i}= & \text { Loading Factor untuk setiap } \mathrm{i} \text { yang } \\
& \text { membangun indikator } \\
\delta \mathrm{i}= & \text { Standard error untuk butir ke } \mathrm{i}
\end{aligned}
$$

dengan nilai loading factor $\lambda>0.3$ untuk tiap item yang membangun dimensi, sedangkan CR yang cukup baik adalah 0.60 menurut Bagozzi dan Yi yang dijelaskan oleh Ghozali dan Fuad (2012).

\section{Hasil}

Pengujian first order Confirmatory Factor Analysis (CFA) alat ukur refleksi diri adaptif tahap uji coba.

Pada tahap uji coba, alat ukur Refleksi Diri Adaptif mengukur tiga dimensi refleksi diri yaitu reaksi emosi, konten pikiran dan penghindaran yang terdiri dari 99 aitem. Terdapat 45 aitem untuk dimensi reaksi emosi dengan 17 aitem aspek refleksi dan 28 aitem aspek ruminasi, 42 aitem untuk dimensi konten pikiran dengan 15 aitem aspek recounting dan 27 aitem aspek reconstruing, dan 12 aitem untuk dimensi penghindaran dengan 6 aitem aspek mencoba untuk tidak memikirkan peristiwa negatif dan 6 aspek mencoba menekan perasaan tentang peristiwa negatif. Aitem terbagi menjadi 52 aitem favorable dan 47 aitem unfavorable. Peneliti menggunakan

Tabel 4

Cut-offs kriteria model pengukuran

\begin{tabular}{lcccc}
\hline & T-Value & Loading Factor $(\lambda)$ & $\mathrm{CR}$ & $\mathrm{R}^{2}$ \\
\hline $\begin{array}{l}\text { Validitas } \\
\text { Reliabilitas }\end{array}$ & $>1.96$ & $>0.30$ & 0.60 (Baik) & $\begin{array}{l}\text { Besarnya kontribusi item/indikator } \\
\text { pada variabel laten }\end{array}$ \\
\hline
\end{tabular}


metode analisis faktor untuk melakukan uji validitas dan reliabilitas konstruk, dengan hasil analisis sebagai berikut.

\section{Dimensi reaksi emosi}

Dimensi reaksi emosi terdiri dari 45 aitem diuji unidimensionalitasnya apakah benar hanya mengukur reaksi emosi. Hasil CFA menunjukkan model tidak fit, lalu dilakukan modifikasi model untuk memperoleh aitem yang memenuhi kriteria model fit yaitu Chi-Square $=8.54, \mathrm{df}=14, p$-value $=$ $0.85938, \mathrm{RMSEA}=0.000, \mathrm{GFI}=0.98$, AGFI $=$ $0.95, \mathrm{CFI}=1.00$, dan IFI $=1.09$, nilai-nilai tersebut telah memenuhi kriteria fit. Pemeriksaan T-value dilakukan untuk menentukan apakah aitem signifikan dalam mengukur faktor yang hendak diukur dan mengeluarkan aitem yang tidak signifikan $(\mathrm{t}<1.96)$. T-value berturut-turut adalah R3(4.90), R5(3.18), R7(4.58), R13(2.40), R17(1.49), R26(3.64) dan R28(2.83). Sehingga aitem R17 (Secara alami saya adalah orang yang sangat senang mempertayakan sesuatu) dikeluarkan dari model karena tidak signifikan. Pemeriksaan loading factor dilakukan untuk menghitung reliabilitas dengan rumus $\mathrm{CR}$, menghasilkan loading factor aitem berturut-turut $\mathrm{R} 3(0.60), \quad \mathrm{R} 5(0.42), \quad \mathrm{R} 7(0.57), \quad \mathrm{R} 13(0.30)$, R26(0,43), R28(0.35). Hasil perhitungan rumus CR adalah 0.60. Hasil ini menunjukkan reliabilitas konstruk dimensi reaksi emosi cukup baik, artinya keenam indikator reaksi emosi memberikan ukuran reliabel untuk dimensi tersebut.

\section{Dimensi konten pikiran}

Dimensi konten pikiran terdiri dari 42 aitem. Dari hasil modifikasi model diperoleh Chi-Square $=109.08, \mathrm{df}=90, p$ value $=0.084$, RMSEA $=0.046$. Nilai tersebut menunjukkan bahwa model fit artinya model dengan satu faktor (unidimensional) bahwa seluruh aitem mengukur satu faktor saja yaitu konten pikiran. Kriteria Goodness of fit lainnya untuk dimensi konten pikiran yaitu nilai $\mathrm{GFI}=0.87$, $\mathrm{AGFI}=0.83, \mathrm{CFI}=$ 0.97 dan IFI $=0.97$. Nilai GFI dan AGFI tidak memenuhi kriteria fit karena kurang dari 0.90 tetapi nilai CFI dan IFI lebih dari 0.90 telah memenuhi kriteria fit, sehingga dikatakan model dapat diterima. T-value aitem-aitem yang memenuhi kriteria model fit adalah K1(6.05), K2(4.65), K3(5.58), $\mathrm{K} 5(3.55), \quad \mathrm{K} 6(5.86), \quad \mathrm{K} 7(2.46), \quad \mathrm{K} 12(7.09)$, K13(3.57), K14(4.38), K15(6.08), K19(4.99), K28(4.64), K34(6.06), K40(5.48), dan K41(8.07). Seluruh aitem tersebut signifikan $(t>1.96)$ dan dapat mengukur dimensi konten pikiran. Dari hasil pemeriksaan loading factor $\mathrm{K} 1(0.59), \mathrm{K} 2(0.47), \quad \mathrm{K} 3(0.55), \quad \mathrm{K} 5(0.37)$, $\mathrm{K} 6(0.57), \mathrm{K} 7(0.26), \mathrm{K} 12(0.67), \mathrm{K} 13(0.37)$, K14(0.45), K15(0.59), K19(0.50), K28(0.47), K34(0.58), K40(0.54), dan K41(0.74), hanya $\mathrm{K} 7$ yang memiliki loading factor kurang dari 0.30, oleh karena itu aitem K7 dikeluarkan dari model. Reliabilitas untuk dimensi konten pikiran yang dihitung dengan rumus $\mathrm{CR}$ adalah 0.85 yang berarti konstruk untuk dimensi konten pikiran memiliki reliabilitas yang baik dan empat belas indikator konten pikiran memberikan ukuran reliabel untuk dimensi tersebut.

\section{Dimensi penghindaran}

Dimensi penghindaran terdiri dari 12 aitem. Hasil pengujian awal diperoleh model yang belum fit, setelah dilakukan modifikasi diperoleh nilai Chi-Square = 21.78, $\mathrm{df}=14, p$-value $=0.083$, RMSEA $=$ $0.075, \mathrm{GFI}=0.94, \mathrm{AGFI}=0.88, \mathrm{CFI}=0.94 \mathrm{dan}$ IFI $=0.94$. Nilai AGFI sebesar 0.88 tidak memenuhi kriteria fit, sedangkan nilai lainnya lebih besar dari 0.90, sehingga model dapat diterima dan aitem-aitemnya dapat mengukur dimensi penghindaran. $T$ value untuk aitem-aitem dimensi penghindaran adalah P3(5.00), P4(4.89), 
P5(6.00), P6(1.73), P7(6.66), P9(7.33) dan P12(0.96). Aitem P6 dan P12 dikeluarkan dari model karena T-value kurang dari 1.96. Hasil pemeriksaan loading factor diperoleh P3(0.54), P4(0.51), P5(0.61), P7(0.69), dan P9(0.74). Seluruh loading factor telah memenuhi kriteria $(>0.30)$, dan hasil perhitungan reliabilitas adalah $\mathrm{CR}=0.76$. Dapat dikatakan bahwa dimensi penghindaran memiliki reliabilitas konstruk yang baik, dan kelima aitemnya memberikan ukuran yang reliabel untuk dimensi tersebut. Proses tersebut dirangkum sebagaimana tabel 5 .

Berdasarkan hasil pengujian pada tahap uji coba diperoleh alat ukur Refleksi Diri Adaptif dengan 25 aitem yang terdiri dari dimensi reaksi emosi dengan 6 aitem yaitu R3, R5, R7, R13, R26, dan R28, dimensi konten pikiran dengan 14 aitem yaitu $\mathrm{K} 1$, K2, K3, K5, K6, K12, K13, K14, K15, K19, K28, K34, K40, dan K41, dan dimensi penghindaran dengan 5 aitem yaitu P3, P4, P5, P7, dan P9, seperti pada tabel 6.

Pengujian First Order Confirmatory Factor Analysis (CFA) alat ukur rerfleksi diri adaptif 25 aitem.

Pernyataan yang membentuk alat ukur Refleksi Diri Adaptif (RDA) tahap uji coba

Tabel 5

Analisis CFA alat ukur refleksi diri adaptif tahap uji coba

\begin{tabular}{lccc}
\hline & \multicolumn{3}{c}{ Dimensi } \\
\hline Goodness of fit & Reaksi Emosi & Konten Pikiran & Penghindaran \\
\hline X2-Chi Square & 8.54 & 109.8 & 21.78 \\
Probability & 0.859 & 0.084 & 0.083 \\
RMSEA & 0.000 & 0.046 & 0.075 \\
GFI & 0.98 & 0.87 & 0.94 \\
AGFI & 0.95 & 0.83 & 0.88 \\
CFI & 1.00 & 0.97 & 0.94 \\
IFI & 1,09 & 0.97 & 0.94 \\
Reliabilitas (CR) & $\mathbf{0 . 6 0}$ & $\mathbf{0 . 8 5}$ & $\mathbf{0 . 7 6}$ \\
Item dengan $\mathrm{R}^{2}$ terbesar & $0.36(\mathrm{R} 3)$ & $0.54(\mathrm{~K} 41)$ & $0.54(\mathrm{P} 9)$ \\
\hline
\end{tabular}

terdiri dari 25 aitem. Aitem tersebut terdiri dari tiga dimensi yaitu dimensi reaksi emosi sebanyak enam aitem, dimensi konten pikiran sebanyak 14 aitem dan dimensi penghindaran sebanyak lima aitem. Total 25 aitem yang lolos proses uji coba dipaparkan dalam tabel 6. Aitemaitem yang telah memenuhi kriteria validitas dan reliabilitas kemudian kembali menjalani proses pengujian First Order CFA. Peneliti melakukan pengujian First Order CFA terhadap dimensi reaksi emosi, dimensi konten pikiran dan dimensi penghindaran sehingga menghasilkan tiga hasil analisis.

\section{Dimensi reaksi emosi}

Dimensi reaksi emosi terdiri dari enam aitem dengan empat aitem aspek refleksi dan dua aitem aspek ruminasi. Peneliti menguji apakah enam aitem yang ada bersifat unidimensional artinya benar hanya mengukur reaksi emosi. CFA model memperoleh hasil Chi-Square $=14.76, \mathrm{df}=9$, $p$-value $=0.09774$ RMSEA $=0.046$, nilai tersebut menunjukkan bahwa model fit. Model ditunjukkan pada gambar 1. 
Tabel 6

Item alat ukur refleksi diri adaptif lolos proses uji coba

\begin{tabular}{|c|c|c|c|}
\hline \multirow{2}{*}{ Dimensi } & \multirow{2}{*}{ Aspek } & \multicolumn{2}{|c|}{ Nomor Aitem } \\
\hline & & favorable & Unfavorable \\
\hline \multirow[t]{2}{*}{ Reaksi Emosi } & Refleksi & R3, R5, R7, R13 & \\
\hline & Ruminasi & R26, R28 & \\
\hline \multirow[t]{2}{*}{ Konten Pikiran } & Recounting & & $\begin{array}{c}\mathrm{K} 1, \mathrm{~K} 2, \mathrm{~K} 3, \mathrm{~K} 5, \mathrm{~K} 6, \mathrm{~K} 12, \\
\mathrm{~K} 13, \mathrm{~K} 14, \mathrm{~K} 15\end{array}$ \\
\hline & Reconstruing & & $\mathrm{K} 19, \mathrm{~K} 28, \mathrm{~K} 34, \mathrm{~K} 40, \mathrm{~K} 41$ \\
\hline \multirow[t]{3}{*}{ Penghindaran } & $\begin{array}{l}\text { Mencoba untuk tidak } \\
\text { memikirkan }\end{array}$ & P3, P5 & P4 \\
\hline & $\begin{array}{l}\text { Menekan perasaan tentang } \\
\text { peristiwa negatif }\end{array}$ & P9 & P7 \\
\hline & Total Aitem & 9 & 16 \\
\hline
\end{tabular}

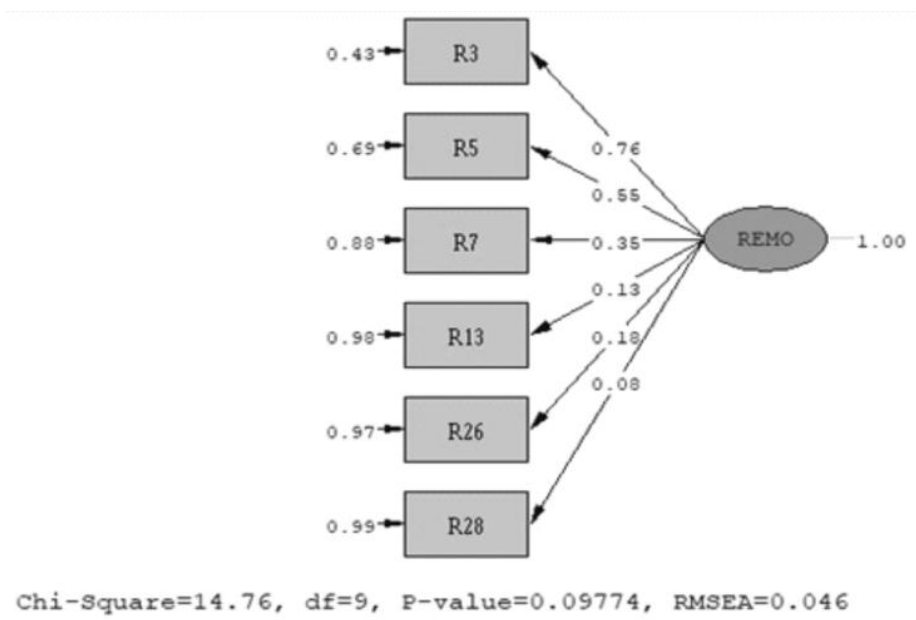

Gambar 1. Standardized Solution CFA Dimensi Reaksi Emosi

Modifikasi terhadap model pengukuran pada dimensi reaksi emosi dilakukan untuk memperoleh aitem-aitem yang valid dan reliabel. Hasil modifikasi model terlihat pada gambar 2 dan gambar 3 .

Nampak pada gambar 2 bahwa hasil $t$ hitung masing-masing aitem lebih besar dari $t$ tabel ( $t>1.96)$. Hal ini menunjukkan bahwa respon yang diberikan responden terhadap aitem-aitem dimensi reaksi emosi dapat mengukur dimensinya secara signifikan. Aitem R3 (Saya pergi sendirian dan berpikir mengapa saya merasa seperti ini) memiliki nilai $\mathrm{R}^{2}$ tertinggi yaitu sebesar 0.52. R3 merupakan indikator yang memberikan kontribusi terbesar terhadap dimensi reaksi emosi sebesar 52 persen.

Pada gambar 3 terlihat seluruh aitem mencapai loading factor yang memenuhi kriteria fit yaitu lebih besar dari 0.30. Selanjutnya dapat dihitung reliabilitas konstruk dengan menggunakan rumus CR. 


\section{BAHIYAH \& SAVITRI}

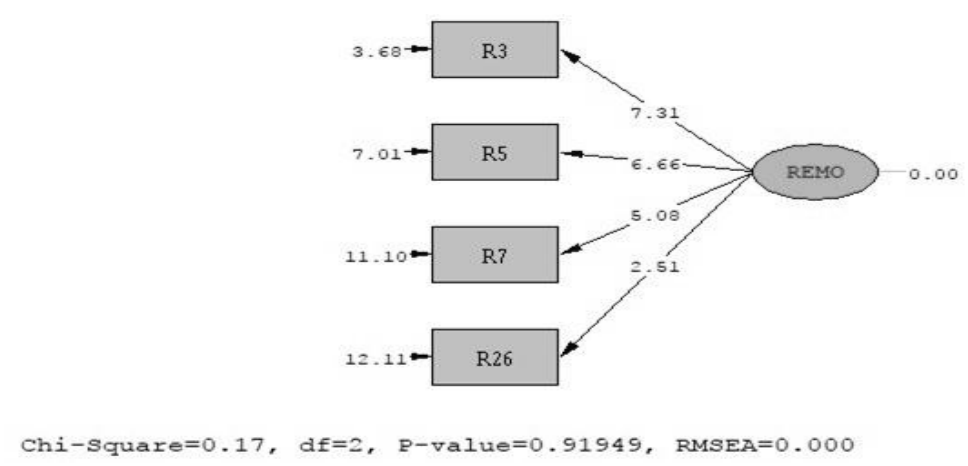

Gambar 2. Hasil Analisis T-Values CFA Dimensi Reaksi Emosi

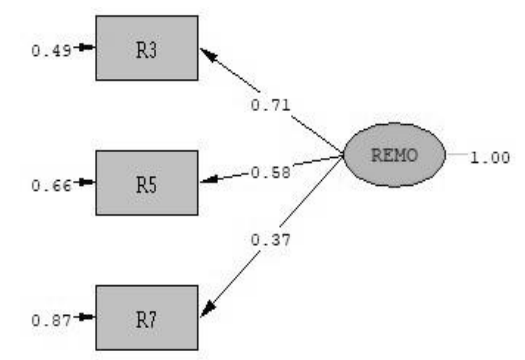

Chi-Square $=0.00, d f=0, p-$ value $=1.00000, \mathrm{RMSEA}=0.000$

Gambar 3. Hasil analisis Standardized Solution CFA dimensi reaksi emosi

Rumus CR yang digunakan sebagai berikut.

$$
\begin{aligned}
& \mathrm{CR}=\frac{\left(\sum_{i=1}^{n} \lambda_{i}\right)^{2}}{\left(\sum_{i=1}^{n} \lambda_{i}\right)^{2}+\left(\sum_{i=1}^{n} \delta_{i}\right)} \\
& \mathrm{CR}=\frac{(2.7556)}{(2.7556)+(2.02)} \\
& \mathrm{CR}=0.58
\end{aligned}
$$

Nilai CR sebesar 0.58 menunjukkan bahwa reliabilitas konstruk untuk dimensi reaksi emosi masih kurang baik. Oleh karena itu keempat indikator reaksi emosi memberikan ukuran yang belum cukup reliabel untuk dimensi reaksi emosi.

\section{Dimensi konten pikiran}

Dimensi konten pikiran terdiri dari 14 aitem dengan 9 aitem aspek recounting dan 5 aitem aspek reconstruing. Peneliti menguji apakah 14 aitem yang ada bersifat unidimensional artinya benar hanya mengukur dimensi konten pikiran. CFA model memperoleh hasil Chi-Square $=35.74$, $\mathrm{df}=26, p$-value $=0.09649$, RMSEA $=0.035$.
Nilai tersebut menunjukkan bahwa model fit artinya model dengan satu faktor (unidimensional). Lihat gambar 4.

Pengujian validitas dan reliabilitas dimensi konten pikiran dapat dilakukan dengan mencermati bentuk output $T$-values seperti gambar 5. Terlihat bahwa respon responden untuk tiap-tiap aitem pada dimensi konten pikiran telah memenuhi kriteria signifikan ( $t>1.96)$.

Berdasarkan analisa data dapat diketahui aitem yang memberikan kontribusi besar terhadap dimensi konten pikiran. Aitem K3 (Ingatan tentang peristiwa yang mengganggu sekecil apapun akan mengganggu saya untuk sementara waktu) dan K6 (Ingatan yang semakin parah muncul di benak saya sebelum saya tertidur) keduanya memiliki nilai $\mathrm{R}^{2}$ tertinggi yaitu sebesar 0.27. K3 dan K6 merupakan indikator yang memberikan kontribusi terbesar terhadap dimensi konten pikiran masing-masing sebesar 27 persen. 


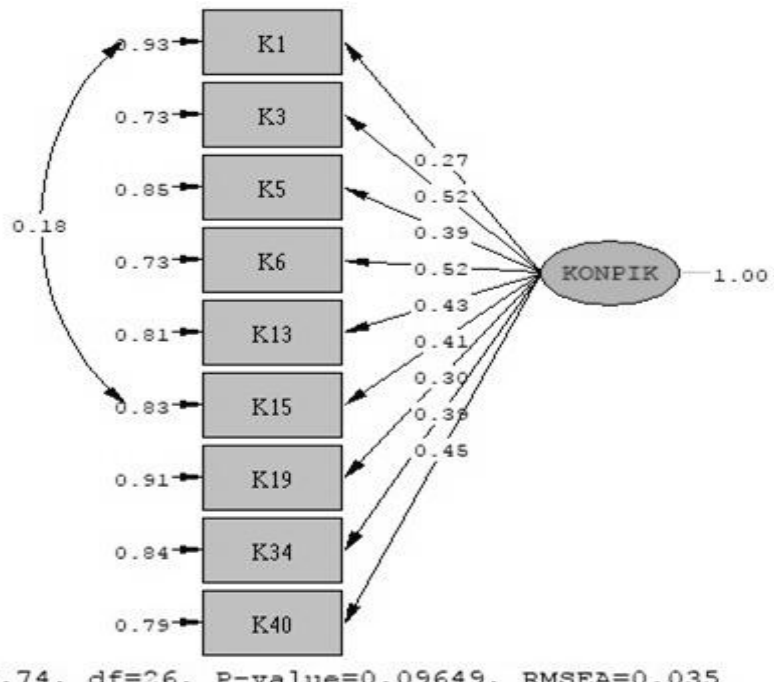

Gambar 4. Standardized Solution CFA Dimensi Konten Pikiran

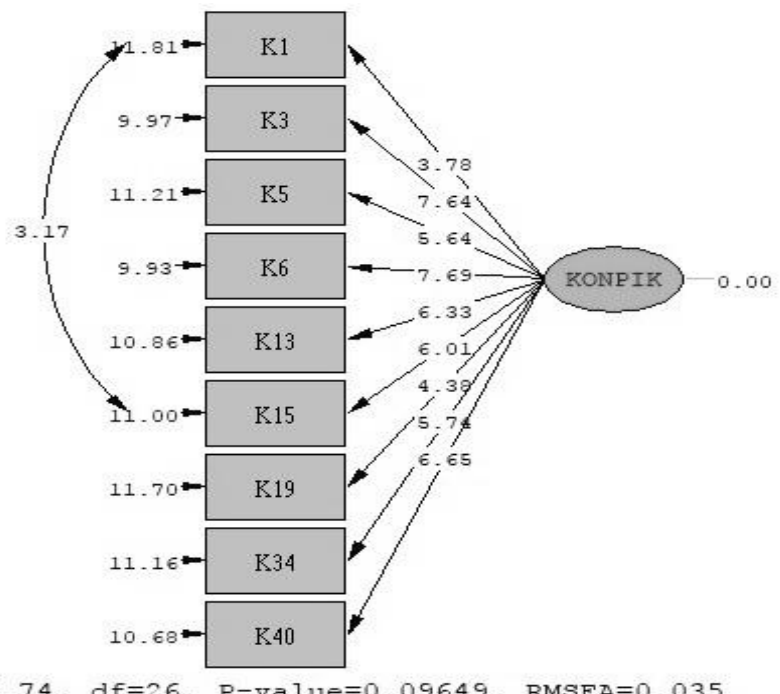

Chi-Square $=35.74, \mathrm{df}=26, \mathrm{P}-\mathrm{value}=0.09649, \mathrm{RMSEA}=0.035$

Gambar 5. T-Values CFA Dimensi Konten Pikiran

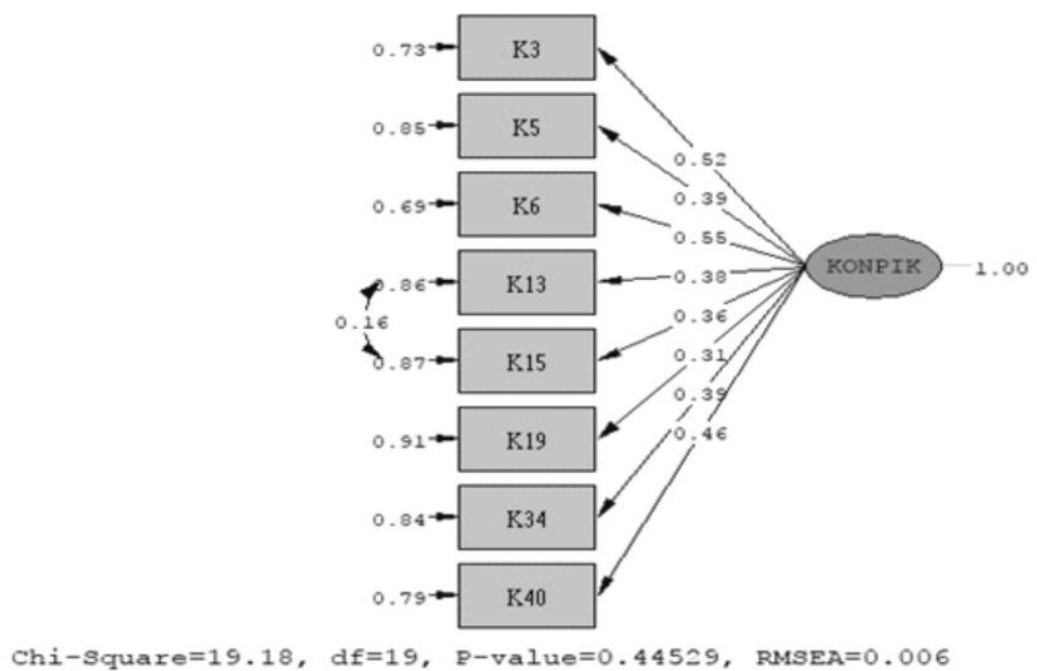

Gambar 6. Hasil Analisis Standardized Solution 
Mencermati informasi yang disajikan dalam gambar 6 tampak bahwa loading factor lebih besar dari 0.3 untuk tiap aitem yang membangun dimensi konten pikiran. Dengan demikian semua butir memiliki kriteria valid, selanjutnya dapat dihitung reliabilitas konstruk dengan rumus $\mathrm{CR}$.

$$
\begin{aligned}
& \mathrm{CR}=\frac{\left(\sum_{i=1}^{n} \lambda_{i}\right)^{2}}{\left(\sum_{i=1}^{n} \lambda_{i}\right)^{2}+\left(\sum_{i=1}^{n} \delta_{i}\right)} \\
& \mathrm{CR}=\frac{(11.2896)}{(11.2896)+(6.54)} \\
& \mathrm{CR}=0.64
\end{aligned}
$$

Nilai CR sebesar 0.64 menunjukkan bahwa reliabilitas konstruk untuk dimensi konten pikiran cukup baik. Oleh karena itu kedelapan indikator konten pikiran memberikan ukuran yang reliabel untuk dimensi konten pikiran.

\section{Dimensi penghindaran}

Dimensi penghindaran terdiri dari 5 aitem, dengan 3 aitem untuk aspek mencoba untuk tidak memikirkan dan 2 aitem untuk aspek menekan perasaan tentang peristiwa negatif. Peneliti menguji apakah 5 aitem yang ada bersifat unidimensional artinya benar hanya mengukur penghindaran.
Dari hasil CFA diperoleh hasil Chi-Square $=$ 6.70, $\mathrm{df}=4, p$-value $=0.15233$, RMSEA $=$ 0.047 . seperti pada gambar 7 . Nilai tersebut menunjukkan bahwa model fit artinya model dengan satu faktor (unidimensional) bahwa seluruh aitem mengukur satu faktor saja, yaitu penghindaran.

Output dalam bentuk T-values seperti gambar 8 dilihat untuk mengetahui respon responden terhadap aitem-aitem dalam dimensinya apakah signifikan atau tidak. Nampak bahwa nilai $t$ hitung telah memenuhi kriteria signifikan yakni lebih besar dari $t$ tabel $(t>1.96)$ sehingga disimpulkan bahwa seluruh aitem pada dimensi penghindaran telah memenuhi kriteria dan dapat mengukur dimensi penghindaran secara signifikan. Aitem P9 (Saya sangat tertarik untuk memeriksa apa yang saya pikirkan) memiliki nilai $\mathrm{R}^{2}$ tertinggi yaitu sebesar 0.36. P9 merupakan indikator yang memberikan kontribusi terbesar terhadap dimensi penghindaran sebesar 36 persen. Modifikasi terhadap model pengukuran pada dimensi penghindaran dilakukan untuk memperoleh aitemaitem yang memenuhi kriteria valid.

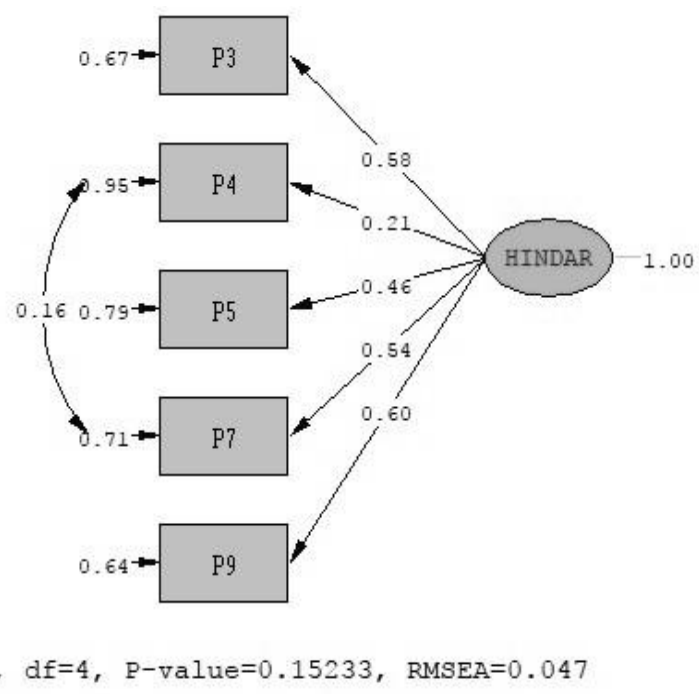

Gambar 7. Standardized Solution CFA Dimensi Penghindaran 


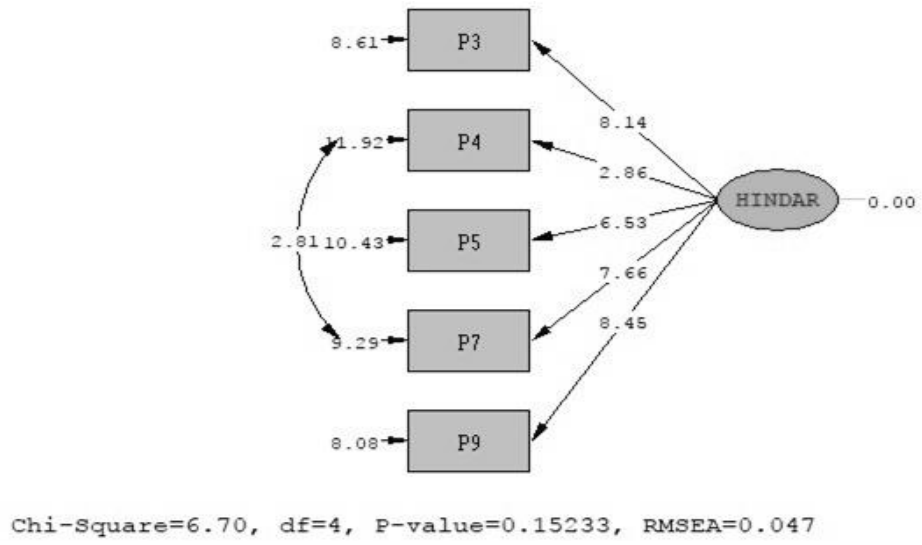

Gambar 8. T-Values CFA Dimensi Penghindaran

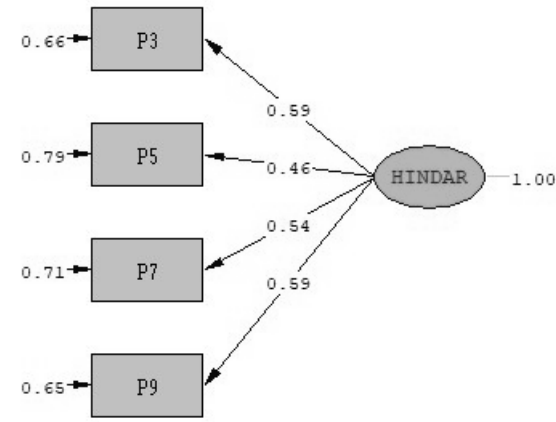

Chi-Square $=1.80, \mathrm{df}=2, \mathrm{P}-\mathrm{value}=0.40719, \mathrm{RMSEA}=0.000$

Gambar 9. Hasil Analisis Standardized Solution CFA Dimensi Penghindaran

Gambar 9 adalah hasil modifikasi model dan selanjutnya dihitung reliabilitas konstruk dengan rumus.

$$
\begin{aligned}
& \mathrm{CR}=\frac{\left(\sum_{i=1}^{n} \lambda_{i}\right)^{2}}{\left(\sum_{i=1}^{n} \lambda_{i}\right)^{2}+\left(\sum_{i=1}^{n} \delta_{i}\right)} \\
& \mathrm{CR}=\frac{(4.7524)}{(4.7524)+(2.81)} \\
& \mathrm{CR}=0.63
\end{aligned}
$$

Dari hasil analisis CFA untuk tiga dimensi yang membangun alat ukur refleksi diri adaptif diperoleh kriteria Goodness of fit, validitas dan reliabilitas aitem seperti dipaparkan pada tabel 7 .

Tabel 7

Hasil analisis CFA tiga dimensi alat ukur refleksi diri adaptif

\begin{tabular}{lccc}
\hline \multirow{2}{*}{ Goodness of fit } & \multicolumn{3}{c}{ Dimensi } \\
\cline { 2 - 4 } & Reaksi Emosi & Konten Pikiran & Penghindaran \\
\hline X2-Chi Square & 14.76 & 33.74 & 6.70 \\
Probability & 0.098 & 0.097 & 0.152 \\
RMSEA & 0.046 & 0.035 & 0.047 \\
GFI & 0.98 & 0.97 & 0.99 \\
AGFI & 0.96 & 0.96 & 0.97 \\
CFI & 0.95 & 0.97 & 0.99 \\
IFI & 0.95 & 0.97 & 0.99 \\
\hline Reliabilitas CR & $\mathbf{0 . 5 8}$ & $\mathbf{0 . 6 4}$ & $\mathbf{0 . 6 3}$ \\
Aitem dengan $\mathrm{R}^{2}$ terbesar & $0.52(\mathrm{R} 3)$ & $0.27(\mathrm{~K} 3, \mathrm{~K} 6)$ & $0.36(\mathrm{P9})$ \\
\hline
\end{tabular}


Pengujian second order Confirmatory Factor Analysis (CFA) alat ukur rerfleksi diri adaptif.

Hasil analisis pengukuran First Order Confirmatory Factor Analysis (CFA) yang dilakukan terhadap model pengukuran refleksi diri adaptif menunjukkan bahwa tiga dimensi refleksi diri adaptif yaitu reaksi emosi, konten pikiran, dan penghindaran, telah memperoleh indikatorindikator yang cukup valid. Aitem-aitem yang membangun model pengukuran yang fit sebanyak 15 aitem.

Gambar 10 menunjukkan hasil pengujian Second Order CFA terhadap 15 aitem yang membangun model pengukuran refleksi diri adaptif menghasilkan ChiSquare $=102.80, \mathrm{df}=84, p$-value $=0.07998$,
RMSEA $=0.027$. Nilai tersebut menunjukkan bahwa model pengukuran fit artinya model pengukuran unidimensional. Model secara teoretis sesuai dengan data empiris. Goodness of Fit model disajikan dalam tabel 8.

Pernyataan-pernyataan yang merupakan aitem alat ukur refleksi diri adaptif hasil analisis CFA dipaparkan pada tabel 9.

Gambar 10 dan gambar 11 merupakan output analisis Standardized Solution dan analisis T-Value Second Order CFA pengukuran refleksi diri adaptif, digunakan untuk memeriksa validitas dan reliabilitas seluruh aitem. Hasil analisis seperti pada tabel 10 .

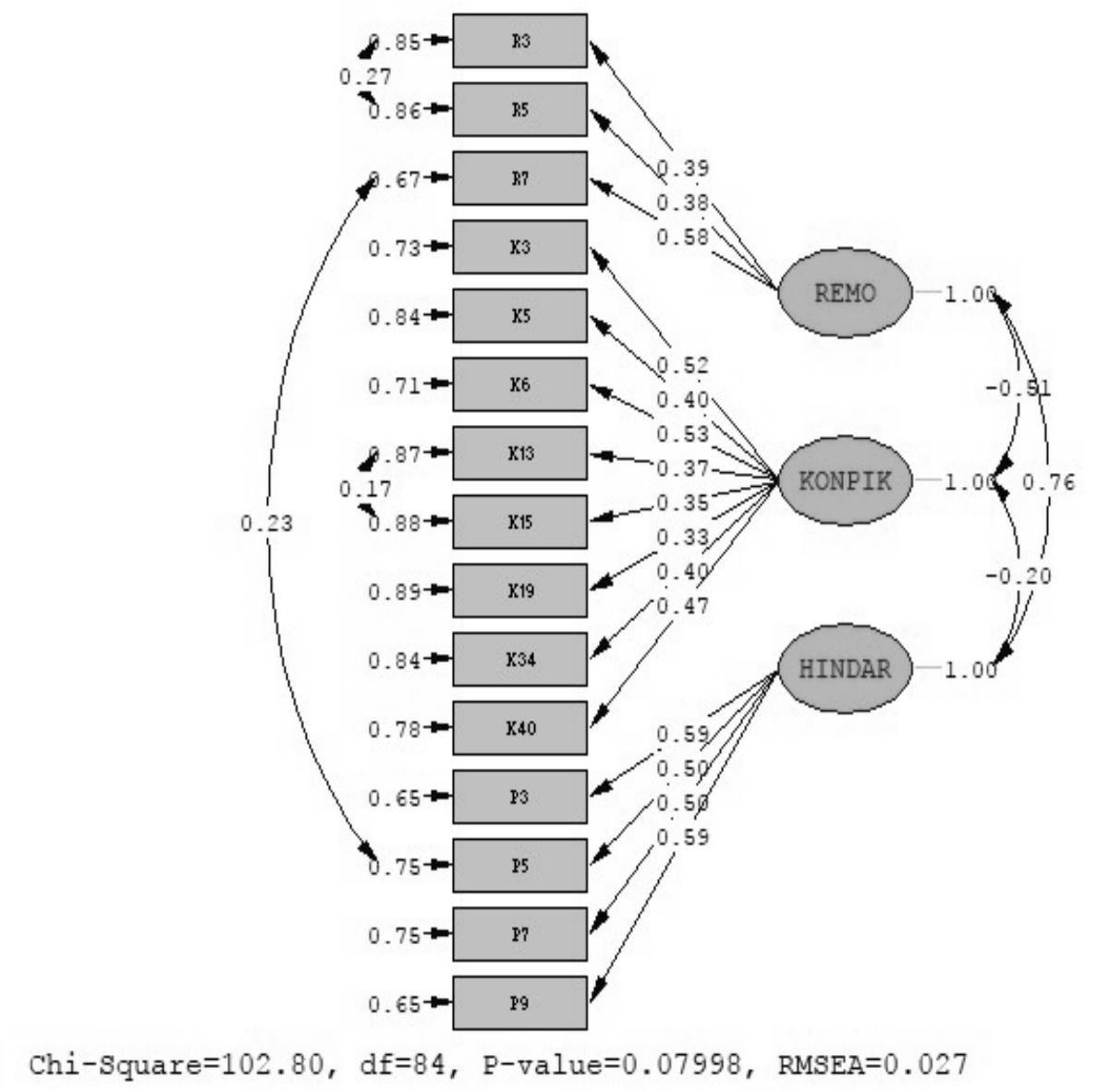

Gambar 10. Standardized Solution Second Order CFA Alat Ukur Refleksi Diri Adaptif 


\section{ALAT UKUR REFLEKSI DIRI ADAPTIF MELALUI CFA}

Tabel 8

Goodness of fit model alat ukur refleksi diri adaptif

\begin{tabular}{llcc}
\hline \multicolumn{1}{c}{ Goodness of fit Index } & Kriteria 'fit' & Hasil Model & Keterangan \\
\hline $\boldsymbol{X}^{2}$-Chi square & - & 102.80 & $\begin{array}{c}\text { Diharapkan } \\
\text { kecil }\end{array}$ \\
& & & Baik \\
Probability & $>0.05$ & 0.07998 & Baik \\
RMSEA & $<0.08$ & 0.027 & Baik \\
GFI & $>0.9$ & 0.96 & Baik \\
AGFI & $>0.9$ & 0.94 & Baik \\
CFI & $>0.9$ & 0.98 & Baik \\
IFI & $>0.9$ & 0.98 & \\
\hline
\end{tabular}

Tabel 9

Aitem alat ukur refleksi diri adaptif

\begin{tabular}{cc}
\hline Aitem & Pernyataan \\
\hline Reaksi Emosi \\
R3 $\quad$ Saya pergi sendirian dan berpikir mengapa saya merasa seperti ini. \\
R5 & Saya pergi ke suatu tempat sendirian untuk memikirkan perasaan saya. \\
R7 & Merenungkan diri sendiri merupakan sesuatu yang saya sukai. \\
Konten Pikiran \\
K3 $\quad$ Ingatan tentang peristiwa yang mengganggu sekecil apapun akan mengganggu saya untuk \\
K5 $\quad$ Sementara waktu. \\
Ketelah argumentasi seseorang berakhir, saya terus bertarung dengan orang ini dalam \\
K6 $\quad$ Ingatinasi saya. \\
K13 $\quad$ Saya merasa marah dengan hal-hal tertentu dalam hidup saya. \\
K15 $\quad$ Saya memikirkan kejadian tertentu yang sudah lama berlalu dan hal itu masih membuat saya \\
K19 $\quad$ marah. \\
K34a saat-saat saya tidak bisa berhenti disibukkan dengan konflik tertentu. \\
K40 $\quad$ Saya akan mengalami depresi jika saya tidak berhenti mengulas pemiikiran kritis diri saya. \\
Penghindaran \\
P3 $\quad$ Saya sering mengevaluasi perasaan saya. \\
P5 $\quad$ Saya sering meluangkan waktu untuk merenungkan pemikiran saya. \\
P7 $\quad$ Saya tidak terlalu tertarik untuk menganalisis perilaku saya. \\
P9 $\quad$ Saya sangat tertarik untuk memeriksa apa yang saya pikirkan.
\end{tabular}




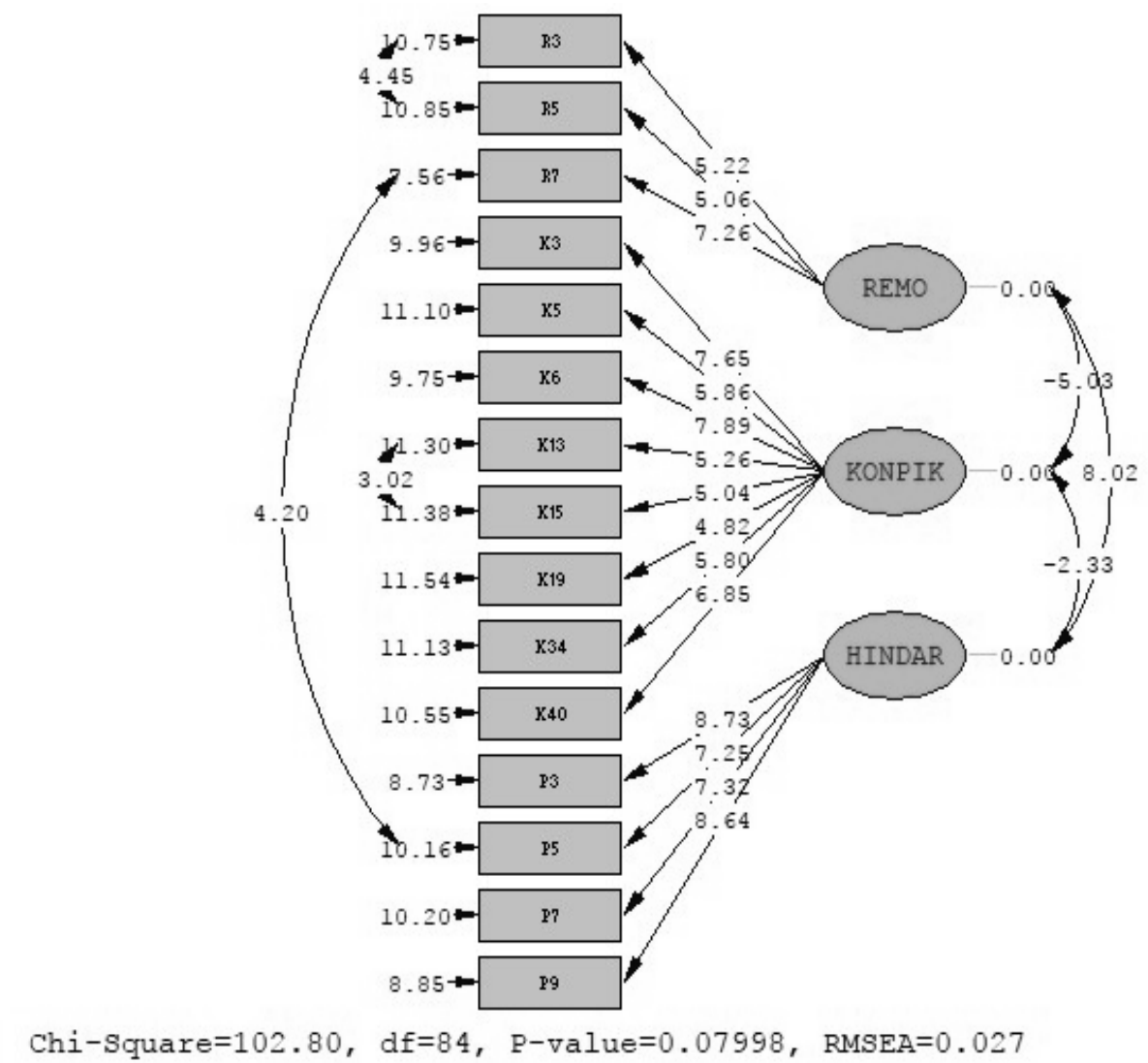

Gambar 11. T-Value Second Order CFA Alat Ukur Refleksi Diri Adaptif

Tabel 10

Hasil second order CFA alat ukur refleksi diri adaptif

\begin{tabular}{lcccc}
\hline \multicolumn{1}{c}{ Item } & $\begin{array}{c}\text { Loading } \\
\text { factor }\end{array}$ & T-value & $\mathbf{R}^{2}$ & Keterangan \\
\hline Dimensi: Reaksi Emosi & & & & \\
Item R3 & 0.39 & 5.22 & 0.15 & Item Fit \\
Item R5 & 0.38 & 5.06 & 0.14 & Item Fit \\
Item R7 & 0.58 & 7.26 & 0.33 & Item Fit \\
Dimensi: Konten Pikiran & & & & \\
Item K3 & 0.52 & 7.65 & 0.27 & Item Fit \\
Item K5 & 0.40 & 5.86 & 0.16 & Item Fit \\
Item K6 & 0.53 & 7.89 & 0.29 & Item Fit \\
Item K13 & 0.37 & 5.26 & 0.13 & Item Fit \\
Item K15 & 0.35 & 5.04 & 0.12 & Item Fit \\
Item K19 & 0.33 & 4.82 & 0.11 & Item Fit \\
Item K34 & 0.40 & 5.80 & 0.16 & Item Fit \\
Item K40 & 0.47 & 6.85 & 0.22 & Item Fit \\
Dimensi: Penghindaran & & & & \\
Item P3 & & & & Item Fit \\
Item P5 & $\mathbf{0 . 5 9}$ & 8.73 & $\mathbf{0 . 3 5}$ & Item Fit \\
Item P7 & 0.50 & 7.25 & 0.25 & Item Fit \\
Item P9 & 0.50 & 7.32 & 0.25 & Item Fit \\
\hline
\end{tabular}


Dari tabel 10 diketahui bahwa aitem P3 (Saya sering mengevaluasi perasaan saya) dan P9 (Saya sangat tertarik untuk memeriksa apa yang saya pikirkan) memberikan kontribusi terbesar untuk alat ukur refleksi diri adaptif dengan nilai $\mathrm{R}^{2}$ masing-masing sebesar 0.35. P3 dan P9 merupakan indikator yang memberikan kontribusi terbesar terhadap dimensi penghindaran sebesar 35 persen. Reliabilitas konstruk alat ukur refleksi diri adaptif dapat dihitung dengan menggunakan rumus CR.

$$
\begin{aligned}
& \mathrm{CR}=\frac{\left(\sum_{i=1}^{n} \lambda_{i}\right)^{2}}{\left(\sum_{i=1}^{n} \lambda_{i}\right)^{2}+\left(\sum_{i=1}^{n} \delta_{i}\right)} \\
& \mathrm{CR}=\frac{(47.8864)}{(47.8864)+(11,72)} \\
& \mathrm{CR}=0.80
\end{aligned}
$$

Nilai CR sebesar 0.80 menunjukkan bahwa alat ukur refleksi diri adaptif memiliki reliabilitas konstruk yang baik, dan kelima belas indikatornya memberikan ukuran yang reliabel untuk alat ukur refleksi diri adaptif.

\section{Diskusi}

Proses pengujian unidimensionalitas model pengukuran serta perhitungan validitas alat ukur refleksi diri adaptif pada tahap uji coba berdasarkan metode Confirmatory Factor Analysis (CFA) memberikan hasil bahwa model pengukuran refleksi diri adaptif dapat diterima sesuai kriteria pengujian. Evaluasi terhadap model pengukuran refleksi diri adaptif berfokus pada hubungan antara dimensi dan aitemaitem penyusunnya. Pemeriksaan validitas aitem dilakukan untuk mengetahui kemampuan aitem-aitem dalam mengukur refleksi diri adaptif, sedangkan konsistensi pengukuran dilakukan dengan pengujian reliabilitas (Ghozali \& Fuad, 2012). Dalam penelitian ini telah melakukan tahap penilaian model fit dan evaluasi model pengukuran yang menghasilkan model yang fit beserta aitem-aitem yang valid. Alat ukur Refleksi Diri Adaptif yang dihasilkan dari penelitian ini terdiri dari 15 aitem yang terbagi menjadi 3 dimensi yaitu dimensi reaksi emosi, dimensi konten fikiran dan dimensi penghindaran.

Pengujian first order CFA terhadap tiga dimensi alat ukur refleksi diri adaptif yang terdiri dari 99 aitem menghasilkan model yang belum fit pada analisis awal karena Chi-Square, p-value, dan RMSEA model pengukuran tidak memenuhi kriteria unidimensional, sehingga peneliti memutuskan kembali melakukan pengujian first order CFA dengan mengeluarkan aitem-aitem yang menyebabkan model pengukuran tidak mencapai unidimensionalitas dengan cara menurunkan nilai Chi-Square (karena diharapkan kecil) untuk mencapai $p$-value sesuai kriteria unidimensional yaitu sebesar 0.05 (Ghozali \& Fuad, 2012). Setelah model pengukuran memenuhi kriteria goodness of fit dan diterima, kemudian peneliti melakukan pengujian validitas dan reliabilitas aitem sehingga diperoleh aitem-aitem yang valid dan reliabel dalam mengukur refleksi diri yang adaptif. Pengujian first order CFA pada tahap uji coba menghasilkan model yang dapat diterima (unidimensional) untuk mengukur refleksi diri adaptif dengan tiga dimensi yang terdiri dari 25 aitem fit. Kemudian model pengukuran dengan 25 aitem ini diuji kembali tiap dimensinya dengan menggunakan metode first order CFA. Analisis awal belum menghasilkan model pengukuran yang fit sehingga dilakukan modifikasi untuk memperoleh model pengukuran unidimensional dengan cara yang sama pada tahap uji coba, sehingga diperoleh model pengukuran yang dapat diterima (unidimensional) dengan 15 aitem fit. 
Pengujian terhadap 15 aitem fit dilakukan dengan menggunakan metode second order CFA. Goodness of Fit model pengukuran refleksi diri adaptif dengan 15 aitem telah memenuhi asumsi unidimensionalitas. Dengan kata lain 15 aitem tersebut merupakan indikator yang valid bagi pengukuran konstruk refleksi diri adaptif. Validitas dan reliabilitas alat ukur refleksi diri adaptif dihitung dengan menggunakan nilai loading factor, standard error, dan $T$ values tiap aitem. Hasil perhitungan diperoleh bahwa 15 aitem fit mengukur refleksi diri adaptif. Hal ini menunjukkan bahwa respon dari responden terhadap aitem-aitem telah memenuhi kriteria signifikan, artinya aitem-aitem tersebut dapat mengukur dimensinya.

Reliabilitas alat ukur refleksi diri adaptif sebesar 0.80 menunjukkan bahwa alat ukur refleksi diri adaptif memiliki reliabilitas konstruk yang baik, dan 15 indikatornya memberikan ukuran yang reliabel sebagai alat ukur refleksi diri adaptif. Hasil analisis dengan metode second order CFA terhadap tiga dimensi yang membangun alat ukur refleksi adaptif menunjukkan korelasi negatif antara dimensi konten pikiran dengan dimensi reaksi emosi sebesar - 0.51, demikian juga korelasi negatif antara dimensi konten pikiran dengan dimensi penghindaran sebesar -0.20 . Sedangkan antara dimensi reaksi emosi dan dimensi penghindaran terdapat korelasi positif sebesar 0.76. Hal ini menunjukkan bahwa dimensi konten pikiran secara independen mengukur refleksi diri adaptif dengan dimensi reaksi emosi, demikian juga secara independen dimensi konten pikiran mengukur refleksi adaptif dengan dimensi penghindaran. Hal ini disebabkan dimensi konten pikiran terdiri dari aitem-aitem unfavorable. Butirbutir unfavorable memiliki potensi untuk mengukur atribut tujuan ukur atau membentuk kelompok butir terpisah dengan butir favorable, selain itu faktor proporsi butir unfavorable yang cukup besar dan kurangnya kemampuan responden dalam memahami butir unfavorable menyebabkan munculnya fenomena ini (Cordery \& Sevastos dalam Widhiarso, 2016). Kondisi ini terjadi karena dalam penelitian ini tidak melakukan pilot study dimana responden diminta untuk melakukan klarifikasi pemahaman dan pemaknaan terhadap aitem-aitem yang disajikan, apakah dapat dimengerti sesuai harapan peneliti atau diperlukan penulisan ulang sehingga responden betul-betul memiliki pemaknaan sebagaimana peneliti inginkan di tiap-tiap aitem. Hal ini merupakan keterbatasan dari penelitian ini yang dapat diperbaiki oleh peneliti selanjutnya.

Terkait jumlah aitem, tidak ada standar yang menyebutkan batasan jumlah aitem yang dapat dikatakan banyak atau sedikit. Pada tahap uji coba 99 aitem yang diuji coba menyisakan 25 aitem, banyaknya aitem yang gugur saat proses analisis disebabkan karena banyak kesalahan pengukuran yang saling berkorelasi satu sama lain. Hal ini dapat disebabkan karena pernyataan-pernyataan yang digunakan pada aitem memiliki kesamaan baik dalam hal kata maupun makna, sehingga menyebabkan aitem kurang bervariasi dalam mengukur refleksi diri adaptif. Selain itu penggunaan adaptasi skala menyebabkan kesalahan penafsiran pada pernyataan yang memungkinkan aitem menjadi tidak sesuai dengan budaya di Indonesia sehingga responden lebih memilih respon normatif.

Perkembangan emosi remaja yang menjadi responden penelitian juga memengaruhi respon terhadap aitem, terkait pengalaman dan perkembangan tiap individu yang berbeda-beda. 
Demikian juga faktor situasi dan kondisi saat pengumpulan data dilakukan, misalnya waktu pengambilan data, tempat dan kondisi fisik responden saat itu. Perbedaan waktu pengambilan data menyesuaikan jadwal belajar responden di kelas juga memengaruhi hasil penelitian. Validitas dan reliabilitas alat ukur menjadi berbeda nilainya. Pengambilan data di pagi hari dimana kondisi dan atensi responden ketika mengerjakan tes masih dalam keadaan baik serta suasana yang kondusif akan berbeda ketika pengambilan data dilakukan pada siang hari dimana atensi responden ketika mengerjakan tes mulai menurun serta kondisi yang tidak lagi kondusif. Jumlah responden pada penelitian juga sangat memengaruhi hasil. Semakin banyak jumlah responden yang di sesuaikan dengan jumlah aitem akan meningkatkan validitas dan reliabilitas alat ukur, dan model pengukuran yang dirancang akan semakin fit.

Kebutuhan terhadap alat ukur refleksi diri diperkirakan semakin meningkat dan meluas. Pengembangan sangat diperlukan untuk mendapatkan alat ukur refleksi diri adaptif yang berkualitas. Alat ukur refleksi diri adaptif yang dirancang dalam penelitian ini dapat digunakan karena terbukti valid dan reliabel untuk mengukur refleksi diri remaja madya (usia 15-18 tahun). Meskipun demikian, masih membutuhkan pengembangan pada penelitian selanjutnya.

\section{Kesimpulan}

Penelitian ini merancang alat ukur Refleksi Diri Adaptif berdasarkan beberapa penelitian terdahulu yang dilakukan oleh Kross dan Ayduk tentang refleksi diri untuk menjawab pertanyaan mengenai kebiasaan mental umum tentang perbedaan antara merenung dengan berpikir secara konstruktif mengenai suatu masalah dan bagaimana seseorang menghadapi emosi negatif yang normal tanpa melakukannya secara berlebihan. Peneliti memperoleh model pengukuran dengan tiga dimensi. Dimensi tersebut adalah reaksi emosi, konten pikiran dan penghindaran. Dimensi reaksi emosi merupakan reaksi yang timbul saat subjek mengingat peristiwa negatif di masa lalu berupa perasaan kecewa, marah, sakit dan reaksi fisik. Pada saat ini individu menilai emosinya. Dimensi konten pikiran adalah hal yang muncul dalam pemikiran responden ketika memikirkan pengalaman marah dan dimensi penghindaran merupakan usaha responden untuk menghindar dari memikirkan kejadian yang membuatnya marah ketika diminta untuk mengingatnya. Seseorang dikatakan telah mencapai refleksi diri adaptif apabila dapat bereaksi secara positif ketika mengingat peristiwa negatif yang pernah dialaminya dengan melakukan refleksi diri menggunakan perspektif self-distancing yaitu merefleksikan emosi dengan cara membiarkan diri merekonstruksi perasaan dan makna dari pengalaman daripada mengulang apa yang telah terjadi dan apa yang dirasakan secara nyata. Semakin responden menjauhkan diri secara spontan ketika merenungkan pengalaman masa lalunya, semakin sedikit menceritakan kejadian tersebut dan semakin merekonstruksinya.

\section{Saran}

Beberapa saran untuk pengembangan alat ukur refleksi diri adaptif ini antara lain menyeimbangkan antara proporsi aitem dengan jumlah responden, melibatkan responden yang lebih banyak sehingga menghasilkan lebih banyak aitem fit, memperhatikan jumlah aitem favorable dan aitem unfavorable untuk menghindari 
kebingunan responden saat memberikan respon, mempertimbangkan ulang penggunaan pilihan respon yang bersifat netral, karena pilihan pada opsi tertentu sangat berbengaruh terhadap alat ukur yang dirancang, memilih waktu pengambilan data yang sama untuk seluruh responden agar diperoleh tingkat validitas dan reliabilitas alat ukur yang lebih baik. Terakhir, penelitian ini melibatkan 100 responden pada tahap uji coba dan 300 responden pada tahap pelaksanaan, seluruhnya adalah siswa SMA berusia 15-18 tahun atau remaja madya, disarankan penelitian selanjutnya melibatkan lebih banyak responden yang lebih heterogen dan tingkat yang lebih tinggi yaitu pada remaja akhir dan dewasa.

\section{Kepustakaan}

Ayduk, Ö., \& Kross, E. (2010). Analyzing negative experiences without ruminating: The role of self-distancing in enabling adaptive self-reflection. Social and Personality Psychology Compass, 4(10), 841-854. doi: 10.1111/ j.1751-9004.2010.00301.x

Eisma, M. C., \& Stroebe, M. S. (2017). Rumination following bereavement: An overview. Bereavement Care, 36(2), 58-64. doi: 10.1080/02682621.2017. 1349291

Fenigstein, A., Scheier, M. F., \& Buss, A. H. (1975). Public and private selfconsciousness. Assessment and Theory, 43(4), 522-527.

Gerace, A., Day, A., Casey, S., \& Mohr, P. (2017). "I think, you think": Understanding the importance of selfreflection to the taking of another person's perspective. Journal of Relationships Research, 8(9), doi: 10.1017/jrr.2017.8
Ghozali, I., \& Fuad. (2012). Structural equation modeling: Teori, konsep, dan aplikasi dengan program LISREL 8.80 Edisi III. Semarang: Universitas Diponegoro

Gillespie, A. (2007) The social basis of selfreflection. In: Valsiner, Jaan and Rosa, Alberto, (eds.). The cambridge handbook of sociocultural psychology. Cambridge Handbooks in Psychology (ed., pp. 678-691). New York, NY: Cambridge University Press.

Grant, A. M., Franklin, J., \& Langford, P. (2002). The self-reflection and insight scale: A new measure of private selfconsciousness. Social Behavior and Personality: An International Journal, 30(8), 821-835. doi: 10.2224/ sbp.2002. 30.8 .821

Kolubinski, D. C., Nikčević, A. V., Lawrence, J. A., \& Spada, M. M. (2017). The metacognitions about self-critical rumination questionnaire. Journal of Affective Disorders, 220, 129-138. doi: 10.1016/j.jad.2017.06.002

Kross, E., \& Ayduk, O (2017). Self distancing theory: Theory, research, and current direction. Article In Press

Kross, E., \& Ayduk, Ö. (2008). Facilitating adaptive emotional analysis: Distinguishing distanced-analysis of depressive experiences from immersed-analysis and distraction. Society for Personality and Social Psychology, 34(7), 924-938. doi: 10.1177/ 0146167208315938

Kross, E., Duckworth, A., Ayduk, O., Tsukayama, E., \& Mischel, W. (2011). The effect of self-distancing on adaptive versus maladaptive selfreflection in children. Emotion, 11(5), 1032-1039. doi: 10.1037/a0021787

Mead, G. H. (1934). Mind, self and society. Chicago: University of Chicago Press. 
Nolen-Hoeksema, S., Wisco, B., \& Lyubomirsky, S. (2008). Rethinkingrumination. Perspectives on Psychological Science, 3, 400-424.

Cejudo, R. J., Salguero, J. M., Dymand, K. L., Sancho, G. E., \& Love, S. (2017). Anger rumination in Australia and Spain: Validation of the Anger Rumination Scale. Australian Journal of Psychology, 69(4), 293-302. doi: 10.1111/ajpy.12154

Retnawati, H. (2016). Analisis kuantitatif instrumen penelitian. Yogyakarta: Parama Publishing.

Sobur, A. (2003). Psikologi umum. Bandung: Pustaka Setia.

Trapnell, P. D., \& Campbell, J. D. (1999). Private self counsciousness and the five factor model of personality: Distinguishing rumination from reflection. Journal of Personality and Social Psychology, 76(2), 284-304.

Treynor, W., Gonzalez, R., \& Hoeksema, S, N. (2003). Rumination reconsidered: A psychometric analysis. Cognitive Therapy and Research, 27(3), 247-259. doi: 10.1023/A:1023910315561

Wade, C., \& Tavris, C. (2007). Psikologi edisi kesembilan. Jakarta : Penerbit Erlangga

Widhiarso, W. (2016). Peranan butir unfavorabel dalam menghasilkan dimensi baru dalam pengukuran psikologi, Jurnal Psikologi Perseptual, 1(1), 40-52. 